\title{
The Quality of Visum et Repertum of Live Victims of Injury Cases \\ In H. Abdul Manan Simatupang General Hospital (RSUD) Kisaran \\ Dated From 1st October 2018 to 31st May 2019
}

\author{
Adrian Rival Djamil ${ }^{a}$, Alfred C. Satyo ${ }^{b}$, Surjit Singh ${ }^{c}$ \\ aadrianrival52@gmail.com
}

\begin{abstract}
Forensic and Medicolegal Department, Faculty of Medicine, Universitas Sumatera Utara, RSUP. H Adam Malik Jl. Bunga Lau No. 17 Medan, 20136, Indonesia
\end{abstract}

\begin{abstract}
Criminal cases often involve not only properties but also human's lives. A way to trace these cases, the police carry out an investigation which will take to the court. In the process of investigating cases involving the life of a person, investigators generally consult expert's assistance, such as doctors in the form of a statement called Visum et Repertum. Making Visum et repertum, an examination report on criminal victims, both living and dead ones, is one of the services provided by general practitioners and forensic medicine who can assist law enforcers in enforcing justice. Visum et repertum is a written statement from a general practitioner (in his capacity as an expert) or a forensic specialist at the official request of law enforcement authorities about what is seen and found in the examined object under an oath.
\end{abstract}

This research is a descriptive study with a cross sectional approach which aims to determine the quality of the Visum et Repertum of live victims of injury cases at RSUD H. Abdul Manan Simatupang Kisaran dated from 1st October 2018 to 31st May 2019, which was conducted at RSUD H. Abdul Manan Simatupang Kisaran from June 2020 to July 2020. The population in this study were all Visum et Repetum data at RSUD H. Abdul Manan Simatupang Kisaran from 1st October 2018 to 31st May 2019. The samples of this study are all data from Visum et Repetum of live victims of injury cases that meet the inclusion and exclusion criteria by total sampling method.

Based on the research obtained from post mortem et repertum data of injuries at RSUD H. Abdul Manan Simatupang from 1st October 2018 to 31st May 2019, it can be concluded that: the number of cases of wounded live victims examined by doctors were as many as 25 cases. The quality of the Visum et Repertum for the injuries of living victims at RSUD H. Abdul Manan Simatupang from 1st October 2018 to 31st May 2019, the VER quality of the preliminary injury was $60 \%$ which was moderate. The quality of the VER for injuries to the news section of $45 \%$, which was not good. The quality of the VER for injuries to the conclusion of $25 \%$, which was not good. The quality of the VER for injuries of $34.6 \%$, which was not good.

Based on the results of this study, it is suggested that Hospital leaders must be aware that Visum et Repertum is a valid document of evidence in lieu of evidence. To be able to make a good visum et repertum, it is necessary to conduct training / workshops for emergency room doctors of RSUD H. Abdul Manan Simatupang Kisaran regarding making visum et repertum.

Keywords: Visum et Repertum; Quality; Injury cases

\section{Introduction}

Criminal cases often involve not only properties but also human's lives. A way to trace these cases is that the police carry out an investigation which will take to the court. In the process of investigating cases involving the life of a person, investigators generally consult expert's assistance, such as doctors in the form of a statement called Visum et Repertum. 
From general or private hospitals and local cliniques, every month there are hundreds of examinations that doctors have to do to make the Visum et Repertum requested by investigators. The most common Visum et Repertum for injuries / visum for injuries are for fights, assault, traffic accidents, and Visum et Repertum for breaches of decency or rape, followed by post mortem.

Making Visum et repertum as a form of report on the results of examination of criminal victims, both living and dead ones, is one of the services provided by general practitioners and forensic medicine / forensic experts who can assist law enforcers in enforcing justice. Visum et repertum is a written statement from a general practitioner (in his capacity as an expert) or a forensic specialist by the official request of law enforcement authorities about what is seen and found in the examined object (the victim's body, whether alive or dead or part of a human body or allegedly part of the human body) under an oath when accepting to examine. The Visum et Repertum in question is one of the evidences in the judiciary, if the production is not correct or lacks quality, then the role of Visum et Repertum in the process of proving a criminal case against human health and soul would not been achieved, which often slows down the process of judges taking court decision of the criminal cases.

Based on the results of several previous studies related to the quality of Visum et Repertum, such as Herkutanto's research in his 1999-2000 study of 977 VeR of live victims in 38 hospitals in Jakarta, it appears that most of the VeRs in various hospitals still need improvement. (Herkutanto, 2005).

Another study by Fadlan Tri Ramadhan, Dedi Afandi, Laode Burhanuddin Mursali who examined the quality of post mortem at RSUD DR.RM.PRATOMO Siapi-api chart for the period of 2009-2013 showed that the quality of Visum et Repertum also needs improvement.

Several researchers had previously examined the quality of Visum et Repertum in several district / city government hospitals, but there had been no study or research at RSUD H Abdul Manan Simatupang Kisaran.

Visum et Repertum is a statement made by a doctor by the request of an authorized investigator regarding medical examinations, whether alive or dead or parts of the human body, based on their knowledge and under an oath, for the benefit of justice. (Budiyanto A, Widiatmaka W, Sudiono S, 1997)

The legal basis of Visum et Repertum in the Criminal Procedure Code (KUHAP)

\section{KUHAP Article 133}

2. KUHAP Article 186

3. KUHAP Article 187 (c)

4. KUHAP Article 184

5. Staatsblad (State Gazette) Year 1937 no. 350

Visum et Repertum holds an important role in the process of proving crimes against humans, where Visum et Repertum describes medical examination results contained in the news section which is considered as a substitute for evidence. 
The Visum et Repertum consists of 5 basic frameworks as follow:

\section{Pro Justitia}

The writing of the word "Pro Justitia" at the top left of Visum et Repertum which means for the sake of justice (Pro Justitia). The provisions of a stamp duty are in accordance with the provisions of UURI No. 13/2005 concerning Stamp Duty (adoption. Stamp duty 1921 article 23) all official letters for court cases must be stamped on paper or with the words "Pro Justitia". 31

\section{Introduction}

The introduction contains:

a. The identity of the applicant for Visum et Repertum.

b. The identity of the victim

c. The identity of the doctor who examines/makes the Visum et Repertum.

d. Date and time of request for Visum et Repertum.

e. Date and time of examination.

f. Place of inspection.

3. News or results of examination

The most important part of the post mortem actually lies in this section, where the examining doctor reports the results of his examination objectively according to what was observed, especially seen and found in the examined victim or object. The inspection is carried out systematically from top to bottom so that nothing is left out.

\section{Conclusion}

This part shows the interpretations that are scientifically justified using the facts found by the doctor who makes the Visum et Repertum, related to the aims and objectives of requesting the Visum et Repertum. This section must contain at least 2 elements, namely the type of wound or violence and the degree of qualification of the wound. This sections also shows the cause-and-effect relationship of the disorder, how long the victim is treated and the expectancy of recovery.

\section{Closing}

This section reminds the makers and users of Visum et Repertum that the report is made in fair and justice and under an oath before the examination.

\section{Research Method}

This research is a descriptive study with a cross sectional approach which aims to determine the quality of the Visum et Repertum of live victims of injury cases at the H. Abdul Manan Simatupang General Hospital, Kisaran dated from 1st October 2018 to 31st May 2019, which was conducted at the H. Abdul Manan 
Simatupang General Hospital, Kisaran from June 2020 to July 2020 which includes submitting titles, literature study, reading proposals, collecting and processing data as well as writing and reporting research results. The population in this study were all Visum et Repetum data at the H. Abdul Manan Simatupang General Hospital, Kisaran dated from 1st October 2018 to 31st May 2019. The sample in this study is all data from Visum et Repetum of live victims of injury cases that meet the inclusion and exclusion criteria at the H. Abdul Manan Simatupang General Hospital, Kisaran dated from 1st October 2018 to 31st May 2019. Sampling technique used is total sampling method. The variables studied were all of the Visum et Repertum data on live victims of injury cases.

\section{Results and Discussion}

Based on the field research carried out from 17th to 20th July 2020 at the H. Abdul Manan Simatupang General Hospital, Kisaran, the number of forensic medical services for wounded cases with live victims which were proven by visum et repertum documents dated from 1st October 2018 to 31st May 2019 were 25 cases, while from 1st October 2018 to 31st May 2019 there were 20 cases.

1. VER quality perforating the introduction

The quality of the VER of preliminary injuries at the H. Abdul Manan Simatupang General Hospital from 1st October 2018 to 31 st May 2019 is presented in table 1

Table 1. The quality of the VER of preliminary section injuries at H. Abdul Manan Simatupang General Hospital dated from 1st October 2018 to 31st May 2019

\begin{tabular}{llc}
\hline \multicolumn{1}{c}{ Structure of the VeR } & \multicolumn{1}{c}{ Assessed Elements } & Mean Score \\
\hline Preliminary & Checkpoint & 0.0 \\
& Time of inspection & 2.0 \\
& Subject data & 2.0 \\
& Inspection request data & 1.0 \\
& Examining doctor data & 1.0 \\
\hline Average total score & & 1,2 \\
\hline
\end{tabular}

The quality value of the introduction $=(1,2 \times 1 / 2) \times 100 \%=60 \%$

Based on the study conducted on VER of life-victim injuries at H. Abdul Manan Simatupang General Hospital from 1st October 2018 to 31st May 2019, the quality of the VER for preliminary injuries was $60 \%$, which means moderate.

2. The quality of the VER injury in the news section

The quality of the VER of the injury to the news section at the H. Abdul Manan Simatupang General Hospital from 1st October 2018 to 31 st May 2019 is presented in table 2

Table 2. The quality of the VER of the coverage at the H. Abdul Manan Simatupang General Hospital dated from 1st October 2018 to 31st May 2019

\begin{tabular}{lll}
\hline Structure of the VeR & Assessed Elements & Mean Score
\end{tabular}




\begin{tabular}{llc}
\hline Preaching & History & 0.0 \\
& Vital Sign & 0.0 \\
& Wound Characteristics & 1,8 \\
& Wound size & 1.7 \\
& Medicine and Care & 0.9 \\
& & \\
\hline Average total score & & 0,9 \\
\hline
\end{tabular}

The value of the quality of the news section $=(0.9 \times 5 / 10) \times 100 \%=45 \%$

Based on the study which was conducted on VER of life-victim injuries at the H. Abdul Manan Simatupang General Hospital dated from 1st October 2018 to 31st May 2019, the quality of the VER for injury in the news section was $45 \%$, which was not good.

3. The quality of the VER wound in the Conclusion section

The quality of the VER for injuries in the Conclusion section at H. Abdul Manan Simatupang General Hospital dated from 1st October 2018 to 31st May 2019 is presented in table 3.

Table 3. The quality of the VER of the injury to the conclusion section at the H. Abdul Manan Simatupang General Hospital dated from 1st October 2018 to 31st May 2019

\begin{tabular}{lcc}
\hline \multicolumn{1}{c}{ Structure of VER } & Assesed Elements & Mean Score \\
& & \\
\hline Conclusion & Types of injuries and violence & 1.0 \\
& Wound qualification & 0.0 \\
\hline Average total score & & 0.5 \\
\hline
\end{tabular}

The quality value of the conclusion $=(0.5 \times 8 / 16) \times 100 \%=25 \%$

Based on the study which was conducted on the VER of life victims' injuries at the H. Abdul Manan Simatupang General Hospital dated from 1st October 2018 to 31st May 2019, the quality of the VER for injury to the conclusion was $25 \%$, which was not good.

4. The quality of the VER wound

The quality of the VER of injuries at the H. Abdul Manan Simatupang General Hospital from dated from 1st October 2018 to 31 st May 2019 is presented in table 4

Table 4. The VER quality of injuries at H. Abdul Manan Simatupang General Hospital dated from 1st October 2018 to 31 st May 2019

\begin{tabular}{lcccc}
\hline \multicolumn{1}{c}{ Structure of VeR } & Mean Score & Value & Mean Score \\
\hline Preliminary & 1,2 & 1 & 1,2 \\
Preaching & 0,9 & 5 & 4,5 \\
Conclusion & 0.5 & 8 & 4,0
\end{tabular}

Total Score $\mathbf{9 , 7}$

The quality value of the post mortem injury $=(9.7 / 28) \times 100 \%=34.6 \%$

Based on the study conducted on the VER of the life-victim injury at the H. Abdul Manan Simatupang General Hospital dated from 1st October 2018 to 31st May 2019, the quality of the VER of the injury was 34.6\%, which was not good.

From the results of this study, the writing of the post mortem et repertum of injuries at the H. Abdul Manan Simatupang General Hospital dated from 1st October 2018 to 31st May 2019 was of poor quality. These results 
are relatively the same as those produced in Herkutanto's research at a hospital in Jakarta in 1999-2000 and a research by Fadlan Tri Ramadhan, Dedi Afandi, Laode Burhanuddin Mursali who examined the quality of post mortem at RSUD DR. RM. PRATOMO Siapi-api chart in the period of 2009-2013. This was worse than the results of Asan Petrus' research which examined the quality of post mortem at Forsea Hospital in Medan, Haji Hospital and Adam Malik Medan Hospital in 2019.

\section{Conclusion}

Based on the research obtained from post mortem et repertum data of injuries at the H. Abdul Manan Simatupang General Hospital from 1st October 2018 to 31st May 2019, it can be concluded as the following:

1. the number of the wounded cases with live victims examined by doctors as shown by visum et repertum of injuries at the H. Abdul Manan Simatupang General Hospital from 1st October 2018 to 31st May 2019 were 25 cases.

2. The quality of the Visum et Repertum for the injuries of living victims at the H. Abdul Manan Simatupang General Hospital from 1st October 2018 to 31st May 2019 was 60\%, which was moderate.

3. The quality of VER of life-related injuries at the H. Abdul Manan Simatupang General Hospital from 1st October 2018 to 31 st May 2019 was $45 \%$, was not good.

4. The quality of the VER of life-related injuries at the H. Abdul Manan Simatupang General Hospital from 1st October 2018 to 31 st May 2019 was $25 \%$, was not good.

5. The quality of VER of life-victim injuries at the H. Abdul Manan Simatupang General Hospital from 1st October 2018 to 31st May 2019 was 34.6\% which was not good.

\section{Acknowledgements}

We would like to thank the leadership and staff RSUD H. Abdul Manan Simatupang Kisaran who have allowed this study.

\section{References}

Amir Amri, Ilmu kedokteran Forensik Edisi kedua Tahun 2005, Hal:204-215.

Budiyanto Arif dkk, Ilmu Kedokteran Forensik, Edisi pertama, Cetakan kedua, UI, Jakarta, 1997. Hal:5-16.

Hamdani Njowito, Ilmu Kedokteran kehakiman.Edisi kedua, Jakarta, PT Gramedia Pustaka Utama, 1992. Hal:21-30.

Budiyanto A, Widiatmaka W, Sudiono S. Ilmu Kedokteran Forensik. Jakarta : Bagian Kedokteran Forensik Fakultas Kedokteran Universitas Indonesia. 1997.

Dedi Afandi, Tata Laksana dan Teknik Pembuatan Visum et Repertum, Fakultas Kedokteran Universitas Riau. 2017.

Peningkatan Kualitas Pembuatan Visum et Repertum perlukaan pada korban hidup. Disampaikan pada Kongres Nasional Persatuan Dokter Forensik Indonesia. Ciawi, 1997

Afandi D. Visum et Repertum pada korban hidup. Jurnal Ilmu Kedokteran. 2009;3(2):79-84.

Herkutanto. Peningkatan Kualitas Pembuatan Visum et Repertum (VeR) kecederaan di rumah sakit melalui pelatihan dokter Unit Gawat Darurat (UGD). JPMK. 2005;8(3):163-9. 
KUHAP dan KUHP, Sinar Grafika, Jakarta,1998

Pratiwi WS, Afandi D, Masdar H. Gambaran Visum et Repertum Perlukaan di Rumah Sakit Umum Daerah Kuantan Singingi periode 1 Januari 2009 - 31 Desember 2013. Journal FK Volume 2 No. 1 Februari 2015

Wiraagni AI, Widihartono E. Karakteristik Kasus pada Visum et Repertum di RSUP dr. Soeradji Tirtonegoro Klaten 2014-2016. Vol.6, No.2, November 2016, Hal. 163-170

Astuti NW. Analisis tingkat kriminalitas di Kota Semarang dengan pendekatan ekonomi tahun 2010-2012 [skripsi]. Semarang: Fakultas Ekonomi dan Bisnis Universitas Diponegoro; 2014.

http://hukumtertulis.com/penjelasan pasal-pasal

http://belajarkedokteran45.com/2015/12/visum-et-repertum-siapa-yang-berhak-dan.html

Murtika IK., Prakoso D. Dasar-dasar ilmu kedokteran kehakiman. Cetakan ke-2. 1992. p 110-112

Dahlan S. Ilmu kedokteran Forensik. Cetakan III. Penerbit Universitas Diponegoro. Semarang. 2004: 177-182.

https://dediafandi.staff.unri.ac.id/files/2010/05/Visum-et-Repertum-pada-korban-hidup.pdf

https://media.neliti.com/media/publications/12542-ID-visum-et-repertum-pada-tahap-penyidikan-

dalammengungkap-tindak-pidana-pemerkosaa.pdf

http://badiklat.kejaksaan.go.id/eakademik/uploads/modul/0648298f903bfdfed2e0677366080bf5.pdf

https://media.neliti.com/media/publications/43243-ID-peranan-dokter-forensik-dalam-pembuktian-perkara-

pidana.pdf

https://luk.staff.ugm.ac.id/atur/UU29-2004PraktikKedokteran.pdf

https://asahankab.bps.go.id/statictable/2017/03/06/101/letak-dan-geografi-kabupaten-asahan-2015.html

https://sumateranews.co.id/2019-angka-kriminalitas-di-wilayah-hukum-polres-asahan-menurun 